\title{
Genetic Variability of Brycon orbignyanus (Valenciennes, 1850) (Characiformes: Characidae) in Cultivated and Natural Populations of the Upper Paraná River, and Implications for the Conservation of the Species
}

\author{
Renata de Souza Panarari-Antunes ${ }^{1}$, Alberto José Prioli ${ }^{2 *}$, Sônia Maria Alves Pinto Prioli², \\ Alexsandro Sobreira Galdino ${ }^{3}$, Horácio Ferreira Julio Junior ${ }^{2}$ and Laudenir Maria Prioli ${ }^{2}$ \\ ${ }^{I}$ Departamento de Ciências; Universidade Estadual de Maringá; Av. Reitor Zeferino Vaz s/n; 87360-000; Goioerê - \\ PR-Brasil. ${ }^{2}$ Núcleo de Pesquisas em Limnologia, Ictiologia e Aqüicultura; Departamento de Biologia Celular e \\ Genética; Universidade Estadual de Maringá; Av. Colombo, 5790; 87020-900; Maringá - PR - Brasil. ${ }^{3}$ Núcleo de \\ Bioquímica; Universidade Federal de São João Del-Rei; Av. Sebastião Gonçalves Coelho, 400; 35501-296; \\ Divinópolis - MG - Brasil
}

\begin{abstract}
This study aimed to evaluate the genetic variability of $\mathrm{B}$. orbignyanus in cultivated and natural populations of the Upper Paraná River, using molecular RAPD markers and mtDNA control region. Specimens were collected in the Paraná River and in the Piracema fish farm in Maringá, State of Paraná, Brazil. RAPD primers produced 82 loci with consistent expression. The population from the Paraná River showed 28 polymorphic loci, whereas the population from the fish farm presented only 12. Data revealed genetic differentiation between the two populations, although not very pronounced. These results were corroborated by the principal coordinate analysis and by neighbor-joining clustering. The alignment of the D-loop sequences of $\mathrm{B}$. orbignyanus indicated the existence of polymorphism only in the natural population. These data could be helpful for the formulation of management strategies and conservation of the genetic diversity of the species.
\end{abstract}

Key words: freshwater fish, endangered, RAPD, mtDNA, polymorphism

\section{INTRODUCTION}

Changes in the aquatic environments have led to numerous consequences for fish populations. The Paraná River basin, for example, has been affected by intense damming of the main rivers, reduction of riparian forests and overfishing. These combined factors have contributed heavily to the decline of populations and even the disappearance of large migratory fishes. The interruption of migration routes, with habitat fragmentation and replacement of lotic by lentic environments, is largely responsible for the extinction of migratory fishes (Sirol and Britto, 2005). In the Upper Paraná River basin, there are some examples of migratory fishes that are now rare, such as Pseudoplatystoma corruscans (pintado), Zungaro zugaro (jaú) and Salminus brasiliensis (dourado).

The genus Brycon comprises about 40 species (Lima, 2003), which are widely distributed in Brazilian river systems, with some species already threatened with extinction. Brycon orbignyanus

*Author for correspondence: ajprioli@ nupelia.uem.br 
(Valenciennes, 1850), known as piracanjuba, is one of these endangered species (Agostinho et al., 1997) and it is already in the category "critically endangered" (Machado, 2005). B. orbignyanus was common in the Paraná River basin, but it has become rare and has not been found in the rivers Tietê, Grande and Paranapanema (Machado et al., 2008).

B. orbignyanus is native to the basins of the Paraná and Uruguay Rivers (Borba et al., 2003). It is omnivorous, rheophilic, and it has high commercial value. It is a large species, reaching up to $79.5 \mathrm{~cm}$ of total length (Godoy, 1975). It is also highly dependent on the presence of riparian vegetation for feeding. In addition to being physical barriers to reproductive migration, one of the consequences of dams is the removal of riparian forests in the reservoirs and in large extensions of flooded tributaries. The critical reduction of $B$. orbignyanus is worrying because of the decrease in the number of individuals and the consequent loss of the population genetic diversity, which could make it even more vulnerable. Therefore, the existence of $B$. orbignyanus in the natural environment has been threatened in the reproductive level and by the drastic reduction of food availability (Agostinho et al., 1994; Agostinho and Júlio Jr., 1999).

With the advent of PCR (Polymerase Chain Reaction), several methods have become available to quantify the genetic variability by the analysis of polymorphisms of DNA fragments. These polymorphisms, associated with morphological and ecological studies have contributed in the recognition of genetic and ecological diversity. The amplification of DNA sequences by PCR and the nucleotide sequencing of DNA are the methods with more emphasis. Nuclear markers such as RAPD (Random Amplified Polymorphic DNA), and sequences of mitochondrial DNA (mtDNA) have been useful in the studies of the genetic structure of populations, phylogeographic relations and phylogenetic reconstruction in fishes (Sivasundar et al., 2001; Liu et al., 2005; Lage and Kornfield, 2006; Antunes et al., 2010).

Molecular studies have been developed with several species of the genus Brycon (Wasko and Galetti, 2002; Barroso et al. 2003; Wasko and Galetti, 2003; Wasko et al. 2004; Santis et al., 2007; Panarari-Antunes et al., 2008; Antunes et al., 2010). However, there are few genetic studies with $B$. orbignyanus, and those assessing the genetic diversity of natural populations are needed, so that they can be used in programs of conservation of the species.

The present study aimed to evaluate the genetic variability of $B$. orbignyanus in cultivated and natural populations of the Upper Paraná River, using molecular markers and sequences of the variable region D-loop of the mtDNA. The results might provide insights for the future programs of conservation of the species.

\section{MATERIAL AND METHODS}

\section{Study Area}

The Paraná River is formed by the confluence of the Rivers Paranaíba and Grande. It is the second river in size in South America and the tenth in flow in the world. Its basin covers more than $10 \%$ of the Brazilian territory, including the States of Goiás, Minas Gerais, São Paulo, Mato Grosso do Sul and Paraná. Its main tributaries are the rivers Tietê, Paranapanema, Iguaçu and Paraguay.

Between the cities of Guaíra and Foz do Iguaçu, in the State of Paraná, the river occupies $170 \mathrm{~km}$ of contiguous stretch between the territories of Brazil and Paraguay, where the reservoir was formed for the Itaipu Hydroelectric Power plant. Downstream of the dam, the river runs its course making the limit between Argentina and Paraguay, and receives its largest tributary, the Paraguay River, forming with the Uruguay River the La Plata basin (http://www.achetudoeregiao.com.br/PR/rio_Paran a.htm).

\section{Sampling}

A total of 60 specimens of B. orbignyanus were collected from the Paraná River in the region of Guaíra (Fig. 1) and from the Piracema fish farm situated in Maringá, Paraná State, Brazil. According to the suppliers of the fish farm, the stock was obtained from the breeders collected in the Baía River $\left(22^{\circ} 43^{\prime} \mathrm{S}\right.$; $\left.53^{\circ} 19^{\prime} \mathrm{W}\right)$. This river is located in the floodplain of the Paraná River, with north to south course, parallel to the right margin of the Paraná River, in the State of Mato Grosso do Sul. Muscle tissues were preserved in commercial alcohol. Specimens of B. orbignyanus from the Paraná River (Nup 249, 1525, 1557, 2473,) were deposited in the Ichthyological Collection of the Research Nucleus in Limnology, Ichthyology and Aquaculture, State University of Maringá. 


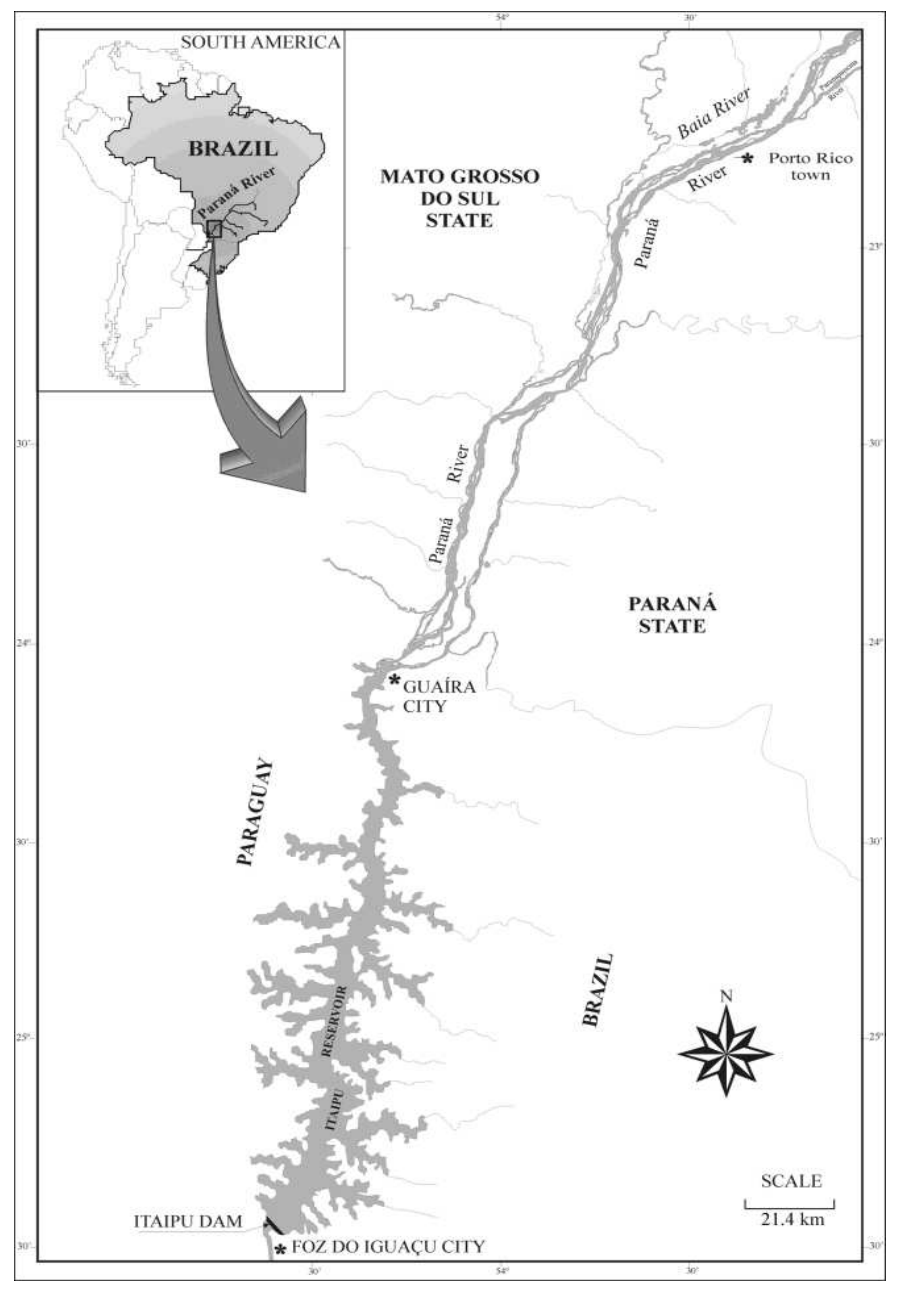

Figure 1 - Study area in the Paraná River.

Extraction and quantification of genomic DNA The extraction of the DNA was carried out using the methodology based on phenol/chloroform (Monesi et al., 1998). The samples of muscle tissue of about $100 \mathrm{mg}$ were macerated in liquid nitrogen. The obtained extract was added to $\mathrm{TH}$ buffer $(10 \mathrm{mM}$ Tris-HCl, $60 \mathrm{mM} \mathrm{NaCl}, 10 \mathrm{mM}$ EDTA, $5 \%$ sucrose, $0.15 \mathrm{mM}$ Spermine and 0.15 $\mathrm{mM}$ Spermidine), PS buffer $(0.2 \mathrm{M}$ Tris- $\mathrm{HCl}, 30$ $\mathrm{mM}$ EDTA, 2\% SDS and 5\% sucrose) and proteinase $\mathrm{K}(20 \mu \mathrm{g} / \mu \mathrm{L})$. Then, the samples were incubated in a water bath with agitation at $37{ }^{\circ} \mathrm{C}$ for about an hour. Next, the DNA was purified through the washes with phenol/chloroform (1:1) and chloroform. The DNA was then precipitated using saline solution $(0.2 \mathrm{M} \mathrm{NaCl})$ and cold ethanol. This precipitate was centrifuged several times with ethanol (70\% and $100 \%)$ and finally resuspended in TE (10 mM Tris, $1 \mathrm{mM}$ EDTA) containing RNase. Subsequently, the DNA of all the samples was quantified in $0.8 \%$ agarose gel stained with ethidium bromide $(20 \mu \mathrm{g} / 100 \mathrm{~mL})$. The quantification consisted in comparing the DNA in $1 \mu \mathrm{L}$ of each sample with known quantities of phage $\lambda$ DNA (Invitrogen).

\section{RAPD and data analysis}

The molecular polymorphism was assessed by the RAPD-PCR technique using 28 specimens of $B$. orbignyanus from the Paraná River and 26 from the fish farm. The two populations were analyzed with the primers RAPD OPX03, OPX05, OPX07, OPX15, OPX18, OPW04, OPW09, OPW17 and OPW19 (Operon Technologies Inc., Alameda, CA, USA). The reaction mixture for amplification of each selected primer consisted of Tris- $\mathrm{KCl}$ buffer (20 mM Tris- $\mathrm{HCl} \mathrm{pH} 8.4$ and $50 \mathrm{mM} \mathrm{KCl}$ ), $2 \mathrm{mM}$ $\mathrm{MgCl}_{2}, 0.46 \mu \mathrm{M}$ primer, $0.19 \mathrm{mM} \mathrm{dNTP}, 1 \mathrm{U}$ 
Taq DNA polymerase (Invitrogen), DNA (10 ng) and enough water to complete $13 \mu \mathrm{L}$. The amplification reactions were performed in the termocycler MJ Research Inc., programmed for 1 cycle of 4 min at $92{ }^{\circ} \mathrm{C}, 40$ cycles of $1 \mathrm{~min}$ at 92 ${ }^{\circ} \mathrm{C}, 1 \mathrm{~min} 30 \mathrm{~s}$ at $40{ }^{\circ} \mathrm{C}$ and $2 \mathrm{~min}$ at $72{ }^{\circ} \mathrm{C}$. Immediately after the last amplification cycle, the reaction mixture was maintained for 5 minutes at $72{ }^{\circ} \mathrm{C}$ and cooled for $20 \mathrm{~min}$ at $20^{\circ} \mathrm{C}$. Negative controls, without DNA mold, were included in each PCR.

About $10 \mu \mathrm{L}$ of the products of the amplified samples were fractionated in $1.4 \%$ agarose gel and taken to an electrophoresis with TBE buffer (TrisBorate), at $5 \mathrm{~V} . \mathrm{cm}^{-1}$, for 4-5 hours. Subsequently, the gel was stained with ethidium bromide (20 $\mu \mathrm{g} / 100 \mathrm{~mL}$ ) for the identification and comparison of the amplified fragments. The visualization of the resulting fragments was performed under ultraviolet light and the gel was photographed for analysis. The size of the fragments could be estimated by comparing the distance of the migrated fragments with the bands of a standard marker (100 pb Ladder - Invitrogen).

Comparisons between the individuals were made to assess the genetic diversity based on the proportion of polymorphic loci within the populations. The diversity index based on the average molecular diversity of all haplotypes loci and the molecular fixation index $\mathrm{F}_{\mathrm{ST}}$, both based on RAPD data, were estimated with the help of the program Arlequin 3.0 (Excoffier et al., 2005). The significance of the molecular index $F_{\mathrm{ST}}$ was determined using a nonparametric permutation procedure. Jaccard`s similarity and the genetic differentiation between the populations were evaluated by applying the Mantel test for the similarity matrix of Jaccard, using the software Mantel-Struct 1.0 (Miller, 1999). The scatter plot in principal coordinates used the arithmetical complements of Jaccard`s similarity after Lingoes correction (Legendre and Anderson, 1999), using the Program DistPCoA (Legendre and Anderson, 1998).

\section{Mitochondrial DNA and data analysis}

The control region of the mitochondrial genome was partially amplified by the PCR from the total DNA of individuals of B. orbignyanus sampled in the Paraná River and in the fish farm. The amplification was performed from five individuals from the fish farm and six from the Upper Paraná River, using the pair of primers D-loop L 5'-
AGAGCGTCGGTCTTGTAAACC-3' (Cronin et al., 1993) and H16498 5'CCTGAAGTAGGAACCAGATG-3' (Meyer et al., 1990). Two independent amplifications were made for the sequencing. In addition, the two strands of each reaction product were sequenced. The mixture of the amplification reaction consisted mostly of Tris- $\mathrm{KCl}(20 \mathrm{mM}$ Tris- $\mathrm{HCl} \mathrm{pH}$ 8.4 and $50 \mathrm{mM} \mathrm{KCl}$ ), $1.5 \mathrm{mM} \mathrm{MgCl} 2,2.5 \mu \mathrm{M}$ of each primer, $0.1 \mathrm{mM}$ of each dNTP , $2.5 \mathrm{U}$ Taq DNA polymerase, $15 \mathrm{ng}$ genomic DNA and autoclaved deionized water to make $25 \mu \mathrm{L}$. The DNA fragment was amplified in 1 cycle of $4 \mathrm{~min}$ at $94{ }^{\circ} \mathrm{C}, 30 \mathrm{~s}$ at $56{ }^{\circ} \mathrm{C}$ and $2 \mathrm{~min}$ at $72{ }^{\circ} \mathrm{C}, 40$ cycles of $15 \mathrm{~s}$ at $94{ }^{\circ} \mathrm{C}, 30 \mathrm{~s}$ at $56^{\circ} \mathrm{C}$ and $2 \mathrm{~min}$ at $72{ }^{\circ} \mathrm{C}$, and a final cycle of $15 \mathrm{~s}$ at $94{ }^{\circ} \mathrm{C}, 30 \mathrm{~s}$ at 56 ${ }^{\circ} \mathrm{C}$ and $10 \mathrm{~min}$ at $72{ }^{\circ} \mathrm{C}$. The samples of DNA (about $50 \mathrm{ng}$ ) amplified in each PCR reaction were used directly in sequencing reactions with BigDye $^{\mathrm{TM}}$ Terminator Cycle Sequencing, in an automated sequencer ABI-3100 (Perkin Elmer), according to the manufacturer's instructions.

Nucleotide sequences were aligned and analyzed using the program Vector NTI Suite version 6.0 (Informax, Inc.). All the mtDNA sequences were aligned with the program CLUSTALW. Genetic analyses of the mitochondrial sequences were performed with the program MEGA 4 (Tamura et al., 2007). The genetic distances of Tamura and Nei were determined between the individuals. The distance matrix was used to construct a dendrogram with the neighbor-joining algorithm, with bootstrap analysis based on 10,000 resampling.

\section{RESULTS}

\section{RAPD}

The nine selected primers produced 82 RAPD loci with consistent expression. The number of distinct and reproducible bands generated per primer ranged from six to ten. Considering the two populations simultaneously, 38 monomorphic loci were found showing that the dominant allele was present in all the analyzed individuals of the two populations. The population of the Paraná River showed 28 polymorphic loci $(34.15 \%)$, six exclusive, while the population from the fish farm presented only $12(14.63 \%)$ and lack of exclusive loci. Figure 2, the electrophoretic profile obtained with primer OPX07, showed greater polymorphism within the population of the Paraná 
River. The estimates of molecular fixation index $\mathrm{F}_{\mathrm{ST}}(0.2026, \mathrm{p}=0.000)$ and Mantel test $(0.3970, \mathrm{p}$ $=0.0001)$ demonstrated genetic differentiation between the two populations, although not very pronounced. The principal coordinate analysis (Fig. 3) and neighbor-joining clustering (Fig. 4), using Jaccard`s similarity between the individuals showed the separation of the two populations. The value of the molecular diversity index was higher for the population of the Paraná River (IM = 0.2691 ), indicating that it was genetically more variable than the population of the fish farm (IM = 0.1196). There was, therefore, agreement between the analyses obtained by the RAPD molecular markers.

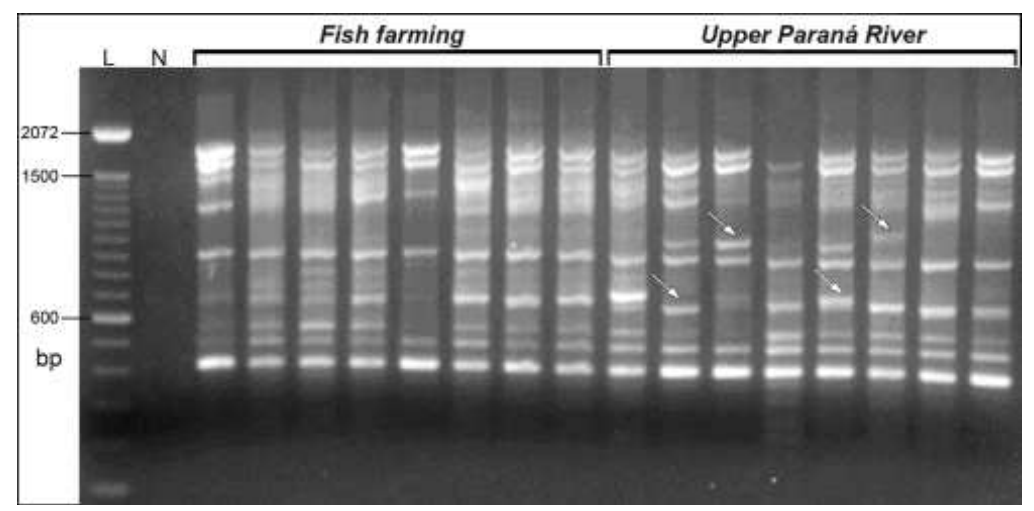

Figure 2 - Electrophoretic profile obtained with primer OPX07 of populations of Brycon orbignyanus from fish farm and the Upper Paraná River. L: contains the marker fragments of molecular weight (100 pb Ladder, Invitrogen), N: negative control, without DNA. Arrows indicate polymorphism.

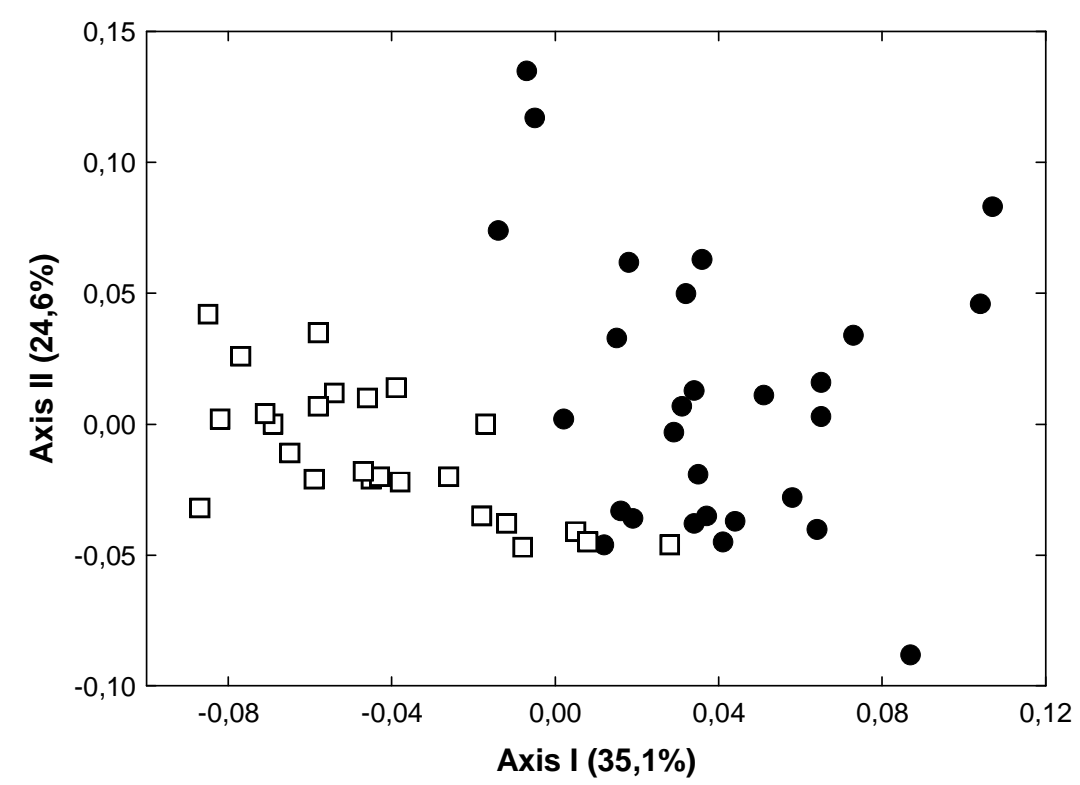

Figure 3 - Scatterplot of principal coordinates, using the arithmetical complements of Jaccard's similarity between individuals of Brycon orbignyanus of populations from fish farm $(\square)$ and the Upper Paraná River $(\bullet)$, based on RAPD molecular markers. 


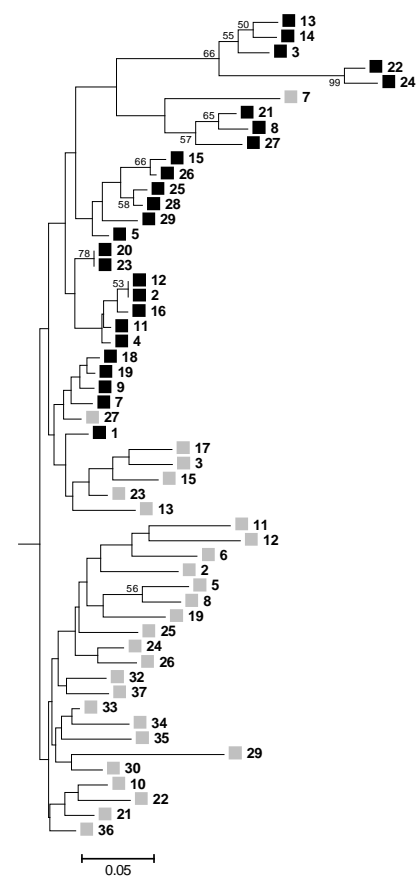

Figure 4 - Neighbor-joining dendrogram, based on RAPD molecular markers, constructed with the arithmetical complements of Jaccard`s similarity between specimens of Brycon orbignyanus of populations from fish farm (匹) and the Upper Paraná River ( $\square$ ).

\section{Mitochondrial DNA}

One fragment of approximately $540 \mathrm{pb}$, corresponding to the D-loop variable region of the mtDNA was sequenced and used for the analysis (Table 1). Polymorphisms were identified between the populations of the natural environment and the fish farm. The population from the Paraná River showed 19 exclusive polymorphic sites, and four exclusive deletions. The replacements were mostly transitions. In addition, the highest nucleotide variability was detected within the population of the Paraná River. The neighbor-joining dendrogram (Fig. 5) using the distances of Tamura and Nei, illustrated the genetic differentiation between the population of the Upper Paraná River and the population of the fish farm. The specimens from the fish farm share a single group, genetically similar. Only one specimen of $B$. orbignyanus from the Upper Paraná River grouped with specimens from the fish farm. For the other specimens, five different haplotypes were identified, one being the genetically closest to the population from the fish farm.

Table 1 - Polymorphic nucleotide sites in sequence (540 pb) of the D-loop hypervariable region of specimens of $B$. orbignyanus from the floodplain of the Upper Paraná River (PR), and fish farm (FF).

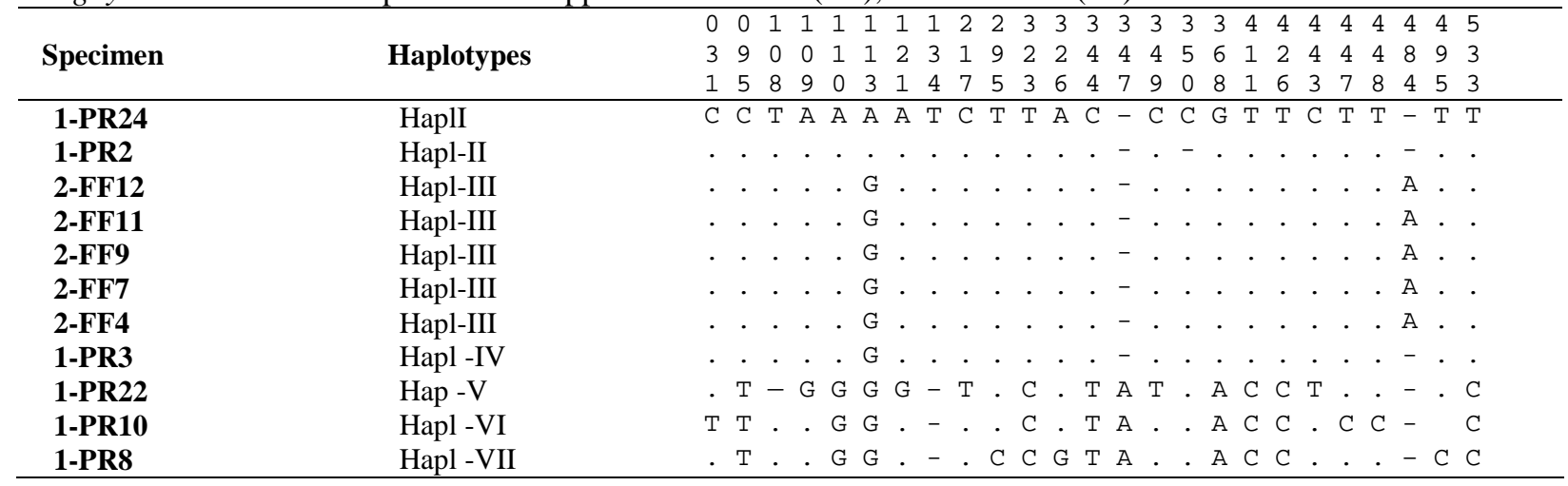




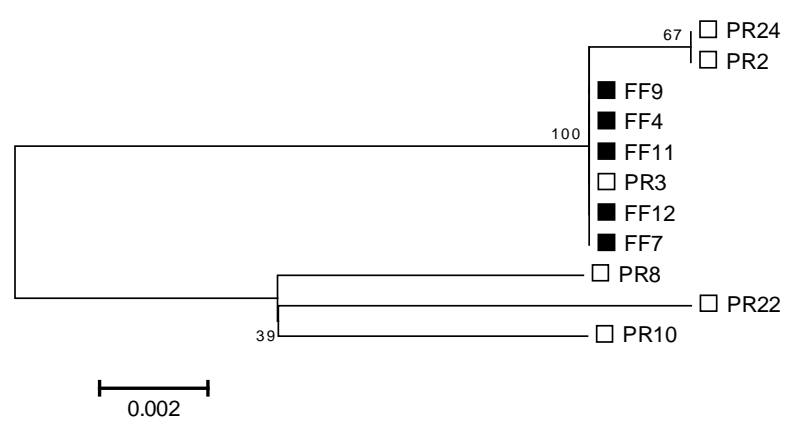

Figure 5 - Neighbor-joining dendrogram obtained with the matrix of the distances of Tamura and Nei, estimated with the D-loop sequences of specimens of B. orbignyanus of populations from fish farm ( $\square)$ and the Upper Paraná River ( $\square$ ).

\section{DISCUSSION}

The intra- and inter-population analysis performed with the data generated by RAPD revealed that the population of $B$. orbignyanus from the Paraná River had higher genetic polymorphism than the population from the fish farm. According to Wright (1978), $\mathrm{F}_{\mathrm{ST}}$ values between 0.15 and 0.25 indicate high genetic differentiation, and values higher than 0.25 indicate that the population was genetically very different. The obtained $\mathrm{F}_{\mathrm{ST}}$ value between the two populations (0.2026) indicate that there was genetic differentiation between them. These results were corroborated by the analysis of the D-loop region of the mtDNA.

The occurrence of higher genetic polymorphism in natural populations is expected, since normally the crosses are given by chance and the possibility of inbreeding is lower. However, some factors may lead to a decline in genetic diversity. Among them are the deterioration of aquatic environments by pollution, sedimentation and construction of dams, overfishing, and introduction of exotic species (Bruton, 1995). In addition, intensive capture of natural populations, or large-scale establishment of populations produced in fingerlings production centers for many generations can change the genetic structure of the species. To prevent or minimize this change, it is important that the breeders used in the crosses for the production of fingerlings, with the purpose of restocking, are representatives of the genetic variability present in the natural environment. Wasko et al. (2004), studying $B$. cephalus, proposed some long-term strategies to maintain the cultivated generations without significant loss of genetic variability. The authors suggested the genotyping of potential breeders before the establishment of the next cultivated stocks, or the crossing of stocks with wild fish populations. The fish farm population analyzed in this study had a high degree of genetic similarity. This could be related to factors such as the use of few breeders, the use of inappropriate reproduction strategies, genetic drift and inbreeding (Wasko et al., 2004; Lopera et al., 2008).

The increase of inbreeding may lead to high homozygosity, allowing rare deleterious alleles to have greater chance of expression, which affects the growth, reproductive performance and increases the abnormalities and mortality (Hansson and Westerberg, 2002; Povh et al., 2005). The studied population from the fish farm was the result of generations obtained with the breeders captured in the Baía River. Thus, another hypothesis to explain its low genetic variability could be that the population of the Baía River might be genetically less variable than the population of the Paraná River. However, it was likely that the number of formers used was not enough to represent the genetic variability of the original population.

The floodplain of the Upper Paraná River in recent years has been characterized by the absence of high flooding. One consequence of this lack of flooding has been the reduction in the recruitment of some species such as B. orbignyanus, which uses the flooded areas for spawning and feeding. This fact compromises even more the survival of the species. Considering that $B$. orbignyanus is seriously threatened with the extinction, the genetic monitoring of its natural populations is 
fundamentally important for the conservation of the species. Natural populations can be genetically structured, i.e., formed by sub-populations with defined genetic composition, adapted and balanced to certain environmental conditions (Foresti et al., 1992). These sub-populations are stocks, and their genetic variability should be identified and considered in the conservation programs for endangered species such as $B$. orbignyanus. Through the study of their natural populations, individuals with varying degrees of diversity can be selected and used as breeders in the restocking programs, introducing the generations obtained from the places where it is threatened or extinct. The genetic diversity of natural populations should be the maintained in populations produced in the fish farms so that the new establishment is successful. In the areas where fishing pressure is high, this procedure becomes even more relevant, since through the use of an appropriate number of formers, captured individuals can be replenished in the environment for generations obtained in a fish farm, without loss of genetic diversity.

Some studies with the species of the genus Brycon have been conducted for conservation purposes, with B. cephalus (Wasko et al., 2004), Brycon lundii (Wasko and Galetti Jr., 2002) and $B$. opalinus (Hilsdorf et al., 2002; Barroso et al., 2003; Barroso et al., 2005). However, few studies with $B$. orbignyanus using molecular markers are found in the literature, which include co-generic species (Wasko et al., 2001; Wasko and Galetti Jr., 2003; Lopera et al., 2008). It is believed that the main factor for this limitation is the difficulty in collecting the specimens of this species. In many places where it was common, now has become rare, or absent. Studies with the microsatellites (Barroso et al., 2003; Barroso et al., 2005), minisatellites (Wasko and Galetti Jr., 2003), spacer DNAr 5S (NTS) and DNAmt (Hilsdorf et al., 2002) have been useful in identifying the species of the genus Brycon and accessing the genetic variability between the populations. However, these methods have high costs and may take more time when sequencing is necessary, as is the case of mtDNA, but can also be applied to NTSs. On the other hand, the RAPD technique used in this work would be faster, has lower costs and has been shown as an effective tool in detecting genetic polymorphism in natural populations (Wasko and Galetti Jr., 2002; Panarari, 2003; Sofia et al., 2006; Theodorakis et al., 2006; Santis et al., 2007), including for genetic monitoring programs of fish restocking (Povh et al., 2009). Lopera et al. (2008) evaluated the genetic diversity of the samples of $B$. orbignyanus used in restocking, using the RAPD technique. The results showed low genetic differentiation between the breeders obtained in different fish farms. However, the genetic variability was maintained in the progeny due to appropriate genetic management practices. Such practices include crossing lots of the breeders with high number of individuals, derived from a sample of specimens that represent the genetic variability present in the natural environment. In addition, RAPD proved to be effective for the detection of genetic variability in the evaluated formers.

In the present study, only one population of $B$. orbignyanus from the natural environment was used, because of its scarcity in many aquatic systems where it was originally found. Nevertheless, it was possible to detect the genetic variability, and to compare it with a population from a fish farm, which showed low polymorphism. The markers were efficient in demonstrating the genetic variability, and therefore their use could be recommended in the identification of natural stocks. Since $B$. orbignyanus is seriously threatened with extinction, the data can support the formulation of strategies for the management and conservation of the genetic diversity of the species. Hence, it is suggested that further efforts should be performed, in order to sample a higher number of sites, so that several specimens can be selected as breeders, aiming to avoid or minimize the genetic losses by inbreeding.

\section{ACKNOWLEDGEMENTS}

The authors are grateful to Dr. Edson Okada for collecting biological material, CAPES, CNPqPELD, and Nupélia (logistic support).

\section{REFERENCES}

Agostinho, A.A., Júlio, Jr H.F. and Petrere, Jr M. (1994), Itaipu reservoir (Brazil): impacts of the impoundment on the fish fauna and fisheries. InRehabilitation of freshwater fisheries, ed. I.G. Cowx. Fishing New Books/Blackwell Scientific Publ. Ltd., London, pp. 171-184. 
Agostinho, A.A., Julio, Jr. H.F., Gomes, L.C., Bini, L.M. and Agostinho, C.S. (1997), Composição; abundância e distribuição espaço-temporal da ictiofauna. In- A Planície de Inundação do Alto Rio Paraná: Aspectos Físicos; Biológicos e SócioEconômicos, ed. A.E.A.M. Vazzoler, A.A. Agostinho and N.S.Hahn. EDUEM, Maringá, pp. 178-208.

Agostinho A.A. and Júlio Jr. H.F. (1999), Peixes da Bacia do Alto Paraná. In- Estudos Ecológicos de Comunidades de Peixes Tropicais, ed. R.H. LoweMcConnell. Universidade de São Paulo, São Paulo, pp. 374-400.

Antunes, R.S.P., Gomes, V.N., Prioli, S.M.A.P., Prioli, R.A., Júlio Jr., H.F., Prioli, L.M., Agostinho, C.S. e Prioli, A.J. (2010), Molecular characterization and phylogenetic relationships among species of the genus Brycon (Characiformes: Characidae) from four hydrographic basins in Brazil. Genet. Mol. Res. 9 (2), 674-684.

Barroso, R.M., Hilsdorf, A. W.S., Moreira, H.L.M., Mello, A.M., Guimarães, E.F., Cabello, P.H. and Traub-Cseko, Y.M. (2003), Identification an characterization of microsatellites loci in Brycon opalinus (Cuvier, 1819) (Characiforme, Characidae, Bryconiae). Mol. Ecol. Notes 3, 297-298.

Barroso, R.M., Hilsdorf, A. W.S., Moreira, H.L.M., Cabello, P.H. and Traub-Cseko, Y.M. (2005), Genetic diversity of wild and cultured populations of Brycon opalinus (Cuvier, 1819) (Characiforme, Characidae, Bryconiae) using microsatellites. Aquaculture 247, 51-65.

Borba, M.R., Fracalossi, D.M., Pezzato, L.E., Menoyo, D. and Bautista, J.M. (2003), Growth, lipogenesis and body composition of piracanjuba (Brycon orbignyanus) fingerlings fed different dietary protein and lipid concentrations. Aquat. Living Resour. 16, 362-369.

Bruton, M.N. (1995), Have fishes had their chips? The dilemma of threatened fishes. Env. Biol. Fish. 43, 127.

Cronin, M.A., Spearman, W.J., Wilmot, R.L., Patton, J.C. and Bickham, J.W. (1993), Mitochondrial DNA variation in chinook (Oncorhynchus tshawytscha) and chum salmon (O. keta) detected by restriction enzyme analysis of Polymerase Chain Reaction (PCR) products. Can. J. Fish. Aquat. Sci. 50, 708-715.

Excoffier, L., Laval G. and Schneider, S. (2005), Arlequin ver. 3.0: An integrated software package for population genetics data analysis. Evol. Bioinform. Online 1, 47-50.

Foresti, F., Toledo-Filho, S.A and Almeida-Toledo, L.F. (1992), Manejo de recursos genéticos em populações de peixes. In- Situação atual $e$ perspectivas da ictiologia no Brasil, ed. A.A. Agostinho and E. Benedito-Cecílio. Editora da UEM, Maringá, pp. 58-68.
Godoy, M.P. (1975), Peixes do Brasil. Subordem Characoidei. Bacia do Rio Mogi Guassu. Vol. II. Piracicaba: Franciscana. Disponível em: <http://www.fishbase.org>. Acesso em : 27 oct. 2009.

Hansson, B. and Westerberg, L. (2002), On the correlation between heterozigosity and fitness in natural populations. Mol. Ecol. 11, 2467-2474.

Hilsdorf, A.W.S., Azeredo-Espin, A.M.L., Krieger, M.H. and Krieger, J.E. (2002), Mitochondrial DNA diversity in wild and cultured populations of Brycon opalinus (Cuvier, 1819) (Characiformes, Characidae, Bryconinae) from the Paraíba do Sul Basin Brazil. Aquaculture 214, 81-91.

Lage, C. and Kornfield, I. (2006), Reduced genetic diversity and effective population size in an endangered Atlantic salmon (Salmo salar) population from Maine, USA. Cons. Genet. 7 (1), 91-104.

Legendre, P. and Anderson, M.J. (1998), Program DistPCoA. Département de sciences biologiques, Université de Montréal.

Legendre, P. and Anderson, M. J. (1999), Distancebased redundancy analysis: testing multispecies responses in multifactorial ecological experiments. Ecol. Monogr. 69, 1-24.

Lopera, N.B., Ribeiro, R.P., Sirol, R.N., Povh, J, Gomes, P, Streit Jr, D. and Vargas L. (2008), Caracterización genética de lotes de Brycon orbignyanus utilizados en programas de repoblamiento. Rev. MVZ Córdoba 13 (1), 11101119.

Lima, F.C.T. Subfamily Bryconinae (Characins, tetras). (2003), In: Check List of the Freshwater Fishes of South and Central America. (Reis R.E., Kullander S.O. and Ferraris Jr. C.J., ed.), pp. 174-181. Porto Alegre: EDIPUCRS.

Liu, H.Z., Zhu, Y.R., Wang, J.W. and Tan, D.Q. (2005), Population genetic structure of an endemic cyprinid fish, Ancherythroculter migrocauda, in the Upper reaches of the Yangtze River and its implication for conservation. Kor. J. Genet. 27 (4), 361-367.

Machado, A.B.M. (2005), Lista da fauna brasileira ameaçada de extinção: incluindo as espécies quase ameaçadas e deficientes em dados. Fundação Biodiversitas, Belo Horizonte.

Machado, A.B.M., Drummond, B.M. and Paglia, A.P. (2008), Livro vermelho da fauna brasileira ameaçada de extinção. 2v. (1420p.). MMA, Brasília, Fundação Biodiversitas, Belo Horizonte.

Meyer, A., Kocher, T.D., Basasibwaki P. and Wilson, A.C. (1990), Monophyletic origin of Victoria cichlid fish suggested by mitochondrial DNA sequences. Nature 347 (6293), 550-553.

Miller, M.P. (1999), Mantel-Struct 1.0. A program for the detection of population structure through the use of Mantel tests. Northern Arizona University. 
Monesi, N., Jacobs-Lorena, M. and Paço-Larson, M.L. (1998), The DNA puff gene BhC4-1 of Bradysia hygida is specifically transcribed early prepupal salivary glands of Drosophila melanogaster. Chromosoma 107 (8), 559-569.

Panarari, R.S. (2003), Variabilidade e estrutura genética de populações de Plagioscion squamosissimus (Perciformes, Sciaenidae) da bacia do rio Paraná. Tese de Mestrado, Universidade Estadual de Maringá, Paraná, Brasil.

Panarari-Antunes, R.S., Prioli, A.J., Prioli, S.M.A.P., Júlio Jr, H.F., Agostinho, C.S. and Prioli, L.M. (2008), Molecular variability in Brycon $c f$. pesu Müller and Troschel, 1845 (Characiformes:Characidae) from the AraguaiaTocantins basin. Genet. Mol. Res. 7 (1), 95-106.

Povh, J.A., Moreira, H.L.M., Ribeiro, R.P., Prioli, A. J., Vargas, L., Blanck, D.V., Gasparino E. and Streit Jr, D. P. (2005), Estimativa da variabilidade genética em linhagens de tilápia do Nilo (Oreochromis niloticus) com a técnica RAPD. Acta Scientiarum 27 (1), 1-10.

Povh, J.A., Ribeiro, R.P., Lopera-Barrero, N.M., Gomes, P.C., Blanck, D.V. Vargas L., Jacometo, C.B. and Lopes, T.S. (2009), Monitoramento da variabilidade genética de pacu, Piaractus mesopotamicus, do programa de aumento de estoque do rio Paranápanema. Arq. Bras. Med. Vet. Zootec.61 (5), 1191-1195.

Santis, H.P., Chacon, L.A., Echavarria, A.E., Inchima, S.U., Molina, D.P., Angel, M.O. and Gomez, J.B. (2007), Characterization of the genetic diversity of the fish Brycon henna (Characiformes: Characidae) in central Columbia with RAPD markers. Rev. Biol. Trop. 55 (3-4), 1025-1035.

Sirol, R.N. and Britto, S.G. (2005), Conservação e manejo da ictiofauna: repovoamento. In- Ecologia de reservatórios: impactos potenciais, ações de manejo e sistemas em cascata, ed. M.G. Nogueira, S.M. Thomaz, R.Henry and A. Jorcin. RiMa, São Carlos, pp. 275-284.

Sivasundar, A., Bermingham, E and Orti, G. (2001), Population structure and biogeography of migratory freshwater fishes (Prochilodus: Characiformes) in major South American rivers. Mol. Ecol. 10 (2), 40717.
Sofia, S.H., Silva, C.R.M., Galindo, B.A., Almeida, F.S., Sodré, L.M.K., Martinez, C.B.R. (2006), Population genetic structure of Astyanax scabripinis (Teleostei, Characidae) from an urban stream. Hydrobiologia 553, 245-254.

Tamura, K., Dudley, J., Nei, M. and Kumar, S. (2007), MEGA4: Molecular Evolutionary Genetics Analysis (MEGA) software version 4.0. Mol. Biol. Evol. 24, 1596-1599.

Theodorakis, C.W., Lee, K.L., Adams, S.M. and Law, C.B. (2006), Evidence of altered gene flow, mutation rate, and genetic diversity in redbreast sunfish from a pulp-mill-contaminated river. Environ. Sci. Technol. 40 (1), 377-386.

Wasko, A.P., Martins, C., Wright, J.M. and Galetti Jr., PM. (2001), Molecular organization of 5S rDNA in fishes of the genus Brycon. Genome 44, 893-902.

Wasko, A.P. and Galetti Jr., PM. (2002), RAPD analysis in the neotropical fish Brycon lundii: genetic diversity and its implications for the conservation of the species. Hydrobiologia 474, 131-137.

Wasko, A.P. and Galetti Jr., PM. (2003), PCR primed with minisatellite core sequences yields speciesspecific patterns and assessment of population variability in fishes of the genus Brycon. J. Appl. Ichthyol. 19, 109-113.

Wasko, A.P., Martins, C., Oliveira, C., Senhorini, J.A. and Foresti, F. (2004), Genetic monitoring of the Amazonian fish matrinchã (Brycon cephalus) using RAPD markers: insights into supportive breeding and conservation programmes. J. Appl. Ichthyol. 20, 4852.

Wright, S. (1978), Evolution and the genetics of populations: Variability within and among natural populations. Vol. 4. University of Chicago Press, Chicago.

Received: June 08, 2010; Revised: September 14, 2010; Accepted: March 28, 2011 